\title{
Grazing effects on spring ecosystem vegetation of California's hardwood rangelands
}

\author{
BARBARA ALLEN-DIAZ AND RANDALL D. JACKSON
}

Authors are associate professor and graduate student researcher, Department of Environmental Science, Policy, and Management-Ecosystem Sciences Division, 151 Hilgard Hall, University of California, Berkeley, Calif. 94720-3110 email: ballen@nature.berkeley.edu

Abstract

Three watersheds at the University of California's Sierra Foothill Research and Extension Center (SFREC), Marysville, Calif. were selected to study cattle grazing effects on the vegetation surrounding cold-water springs and their downslope creeks. Three spring-creek systems from each of 3 watersheds were randomly assigned to grazing treatments ( 9 total). Treatments were ungrazed, lightly grazed $\left(1,500 \mathrm{~kg}^{\circ} \mathrm{ha}^{-1}\right.$ residual dry matter), and moderately grazed $\left(1,000 \mathrm{~kg}^{\circ} \mathrm{ha}^{-1}\right.$ residual dry matter) based on degree of use in upland pastures encircling the spring-creek systems. Total herbaceous cover at springs varied significantly among the 6 years only once (greater in 1994 than all others) covarying with previous year's rainfall. Grazing intensity did not affect total herbaceous cover at springs. A year $X$ grazing treatment interaction $(P<0.05)$ was detected for total herbaceous cover at spring-fed creeks. Three years after grazing removal, total herbaceous cover on ungrazed creek plots surpassed cover at moderately grazed and lightly grazed plots. Moderately grazed plot herbaceous cover declined steadily throughout the first 3 years, while lightly grazed cover remained relatively stable. Plant community composition and stability by year and grazing treatment were analyzed with TWINSPAN. With few exceptions, stable plant communities persisted on sites regardless of grazing intensity or cover changes. Total herbaceous cover was sensitive to interannual fluctuations, especially under increased grazing intensities. This attribute renders cover a more useful gauge of ecosystem health than plant composition as the latter may not provide evidence of potentially deleterious grazing $X$ climate interactions until after soil erosion or water table characteristics are seriously, perhaps permanently, altered.

Key Words: Riparian, creek, cover, grazing, species composition

The ecology and management of California's annual grasslands, woodlands, and savannas have been well studied (Bartolome and Standiford 1992, Bartolome and McClaran 1992, Bartolome et al. 1994, Heady et al. 1992, Standiford et al. 1997). However, few studies examine cold-water spring ecosystems of these rangelands, or the potential for grazing effects on them (Allen-Diaz et al. 1998).

The authors thank James Bartolome and 2 anonymous reviewers for review and comments; Irene Timossi for information system management; Mark Spencer, Clay Taylor, Chris Campbell, Cheryl Lovato Niles, Jeff Fehmi and others for field sampling assistance; and Mike Connor and Sierra Foothill Research and Extension Center personnel for range management. The Integrated Hardwood Range Management Program, University of California funded this project.

Manuscript accepted 10 July 1999.

\section{Resumen}

Se seleccionaron tres cuencas hidrológicas de la Estación de Investigación y Extensión Sierra Foothills de la Universidad de California con el objetivo de estudiar los efectos del apacentamiento del ganado en la vegetación circundante de manantiales de agua fría y sus arroyos pendiente abajo. En cada cuenca, tres sistemas de manantial-arroyos se asignaron aleatoriamente a los tratamientos de apacentamiento ( 9 en total). Los tratamientos fueron; sin apacentamiento, apacentacentado ligeramente $(1,500$ $\mathrm{kg} \mathrm{ha}^{-1}$ de materia seca residual) y apacentacentado moderadamente $\left(1,000 \mathrm{~kg} \mathrm{ha}^{-1}\right.$ de materia seca residual), los tratamientos se basaron en el grado de utilización de tierras arriba que circundan los sistemas de manatial-arroyos. La cobertura total de la vegetación herbácea en los manantiales varió significativamente solo una vez en 6 años (en 1994 fue mayor que los otros años) y los cambios se correlacionaron con la precipitación del año anterior. La intensidad de apacentamiento no afecto la cobertura total de la vegetación herbácea de los manantiales. En la variable cobertura total de la vegetación herbácea de los manantiales-arroyo, se detecto una interacción año $x$ tratamiento de apacentamiento $(P<0.05)$. Después de 3 años de que el apacentamiento se suspendió, la cobertura total herbácea de las parcelas de los arroyos sin apacentar superó a la cobertura registrada en las parcelas con apacentamiento ligero y moderado. La cobertura de herbáceas de las parcelas con apacentamiento moderado disminuyo paulatinamente durante los primeros tres años, mientras que la cobertura de las parcelas con apacentamiento ligero permaneció relativamente estable. La composición y estabilidad de la comunidad vegetal por año y tratamiento de apacentamiento se analizaron con TWINSPAN. Con pocas excepciones, comunidades estables de plantas persistieron en los sitios, independientemente de la intensidad de apacentamiento o los cambios de cobertura. La cobertura total herbácea fue sensible a las fluctuaciones interanuales, especialmente bajo las mayores intensidades de apacentamiento. Este atributo, en comparación con la composición de la comunidad, representa una mejor medida de la salud del ecosistema que este ultima puede no proveer de evidencia del daño potencial de la interacción apacentamiento $x$ clíma hasta que la erosión del suelo o las características de agua freática son seriamente alteradas.

Managers assess range condition or health by comparing existing plant community composition to a standard (Dyksterhuis 1949, Busby et al. 1994). Plant species cover is the variable most often estimated for generating range condition classes. Although grazing management changes often effect changes in vegetation cover, Bartolome (1984) and Milchunas and Lauenroth (1993) 
suggested that species composition does not necessarily track cover variability and may lead to erroneous conclusions concerning long-term ecosystem productivity. Busby and Cox (1994) suggested that soil degradation and water quality parameters may be more important than plant species composition for assessing ecosystem health.

We tested the effects of different cattle grazing intensities on vegetation surrounding springs over 6 years on California's oak-dominated hardwood rangeland. We hypothesized that reduced grazing intensity would induce plant community composition change. However, we held no a priori notions regarding compositional change direction.

\section{Study Site}

Research was conducted at Sierra Foothill Research and Extension Center (SFREC). The study site was described in detail in Allen-Diaz et al. 1998. Briefly, SFREC has an average annual precipita-

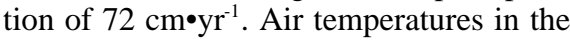
region range from monthly averages of $32.0^{\circ} \mathrm{C}$ in July to $2.2^{\circ} \mathrm{C}$ in January. Dominant vegetation is blue oak (Quercus douglasii Hook. \& Arn.)/gray pine (Pinus sabiniana Douglas) woodlands and savannas with introduced annual grass and forb understories. Soils in this area are classified as Auburn (loamy, oxidic, thermic, Ruptic-Lithic Xerochrepts) and Argonaut (fine, mixed, thermic Mollic Haploxeralfs) series (Herbert and Begg 1969).

As described previously, springs and their resultant creeks are quite small (about $0.5 \mathrm{~m}$ wide at the source). Wetland species (Table 1 for typical spring spp.) remain green in summer and sharply delineate a spring's boundaries, which extend an average of $3 \mathrm{~m}$ perpendicular to flow, forming oval-like borders. The highly palatable, perennial vegetation of spring ecosystems encourages intense cattle use. This is especially evident during summer months as upland annual grasses dry (Table 1 for typical annual grassland spp.). Concentrated utilization of springs creates visually striking vegetation impacts that motivated this study.

Three spring-creek systems were selected from each of 3 SFREC watersheds (Campbell, Schubert, and Forbes) for grazing treatment application (Allen-Diaz et al. 1998). Watersheds were selected for the presence of undeveloped springs, geographic proximity, and similar management histories. These watersheds had all been grazed by cattle at a moderate level
(800 to $1000 \mathrm{~kg} \bullet \mathrm{ha}^{-1}$ residual dry matter) since 1960 when the ranch came under University of California ownership. Prior to this ownership change, it is believed that greater livestock use levels existed (Kinney 1996), however, these use levels have not been quantified. Impediments to wildlife herbivory do not exist, nor do we believe any ever have in the past.

\section{Methods}

\section{Grazing treatment}

Each pasture within a watershed was randomly assigned a grazing treatment, ungrazed (UG), lightly grazed (LG), or moderately grazed (MG); applied from
1993 through 1997 . The approximately 2 ha pastures were grazed by cattle following autumn germination (usually November). Cattle were then removed for the winter and returned to pastures during the spring season annual vegetation rapidgrowth phase (February through April). Residual herbage on a dry matter basis (RDM) estimates were then made and cattle were returned to pastures in May to meet target RDM levels (Table 2 for annual RDM estimates). The number of animals placed in a pasture during any period was variable as it was based on available upland forage. Indeed, more animals were often placed on the lightly grazed plots because of site and interannual productivity differences (Allen-Diaz et al. 1998).

Table 1. Partial herbaceous-layer flora of springs and uplands.

\begin{tabular}{|c|c|c|}
\hline Species & Common name & Family \\
\hline \multicolumn{3}{|l|}{ Springs } \\
\hline Brachypodium distachyon L.. & False brome & Poaceae \\
\hline Briza minor $\mathrm{L}$ & Rattlesnake grass & Poaceae \\
\hline Carduus pycnocephalus L. & Italian thistle & Asteraceae \\
\hline Cynodon dactylon $\mathrm{L}$. & Crabgrass & Poaceae \\
\hline Cynosurus echinatus L. & Dogtail & Poaceae \\
\hline Cyperus niger Ruiz Lopez \& Pavon & Sedge & Cyperaceae \\
\hline Cyperus odoratus L. & Sedge & Cyperaceae \\
\hline Eleocharis macrostachya Britton. & $--^{1}$ & Cyperaceae \\
\hline Holcus lanatus L. & Velvet grass & Poaceae \\
\hline Lolium multiflorum Lam. & Italian ryegrass & Poaceae \\
\hline Mimulus guttatus DC. & Monkey flower & Scrophulariaceae \\
\hline Paspalum dilatatum Poiret & Dallis grass & Poaceae \\
\hline Polypogon monspeliensis L. & Annual beard grass & Poaceae \\
\hline Rorippa nasturtium-aquaticum Hayek & Water cress & Brassicaceae \\
\hline Rubus ursinus Cham. \& Schldl. & Blackberry & Rosaceae \\
\hline Stachys albens A. Gray. & Hedge nettle & Lamiaceae \\
\hline Stellaria media Villars & Common chickweed & Caryophyllaceae \\
\hline Typha angustifolia $\mathrm{L}$. & Cattail & Typhaceae \\
\hline Verbena bonariensis L. & $--^{1}$ & Verbenaceae \\
\hline Vitis californica Benth. & California grape & Vitaceae \\
\hline \multicolumn{3}{|l|}{ Uplands } \\
\hline Avena fatua $\mathrm{L} .$. & Wild oat & Poaceae \\
\hline Bromus diandrus Roth & Ripgut brome & Poaceae \\
\hline Bromus hordeaceus L. & Soft chess & Poaceae \\
\hline Bromus madritensis L. & Red brome & Poaceae \\
\hline Carduus pycnocephalus L. & Italian thistle & Asteraceae \\
\hline Centaurea solstitialis L. & Yellow star thistle & Asteraceae \\
\hline Elymus glaucus Buckley & Blue wildrye & Poaceae \\
\hline Erodium botrys Bertol. & Filaree & Geraniaceae \\
\hline Erodium cicutarium L'Her. ; & Filaree & Geraniaceae \\
\hline Galium aparine $\mathrm{L}$. & Common bedstraw & Rubiaceae \\
\hline Geranium molle L. & Geranium & Geraniaceae \\
\hline Hordeum murinum L. & Barley & Poaceae \\
\hline Lolium multiflorum Lam. & Italian ryegrass & Poaceae \\
\hline Medicago polymorpha L. & California burclover & Fabaceae \\
\hline Nassella pulchra Barkworth & Purple needlegrass & Poaceae \\
\hline Phalaris aquatica $\mathrm{L}$. & Harding grass & Poaceae \\
\hline Taeniatherum caput-medusae Nevski & Medusahead & Poaceae \\
\hline Torilis nodosa L. & Wild carrot & Apiaceae \\
\hline Trifolium hirtum All. & Rose clover & Fabaceae \\
\hline Vulpia myuros C. Gmelin & Annual festuca & Poaceae \\
\hline
\end{tabular}

No known common name 
Table 2. Annual residual dry matter (RDM) estimates made each June from 3 clipped plots in pastures surrounding spring sites to estimate grazing intensity.

\begin{tabular}{|c|c|c|c|c|c|c|c|c|}
\hline \multirow[b]{2}{*}{ Watershed } & \multirow[b]{2}{*}{ Treatment } & \multicolumn{5}{|c|}{ Grazing Year (September-June) } & \multirow[b]{2}{*}{ Mean } & \multirow[b]{2}{*}{ SE } \\
\hline & & $1992 / 3$ & $1993 / 4$ & $1994 / 5$ & $1995 / 6$ & $1996 / 7$ & & \\
\hline & & & & & $\left(\mathrm{kg} \bullet \mathrm{ha}^{-1}\right)$ & & & $\ldots$ \\
\hline \multirow[t]{3}{*}{ Campbell } & $\mathrm{UG}^{1}$ & 2586 & 1404 & 2347 & 1227 & 1478 & 1808 & 274 \\
\hline & $\mathrm{LG}^{2}$ & 1256 & 462 & 2240 & 1066 & 790 & 1163 & 301 \\
\hline & $\mathrm{MG}^{3}$ & 1248 & 798 & 1685 & 1040 & 742 & 1103 & 171 \\
\hline \multirow[t]{3}{*}{ Schubert } & UG & 6092 & 3031 & 5899 & $--^{4}$ & 1915 & 4234 & 1043 \\
\hline & LG & 1453 & 1413 & 3461 & 1592 & 878 & 1759 & 442 \\
\hline & MG & 1597 & 402 & 1013 & 1788 & 578 & 1076 & 272 \\
\hline \multirow[t]{3}{*}{ Forbes } & UG & 5019 & 2648 & 5317 & $--^{4}$ & 3114 & 4025 & 670 \\
\hline & LG & 5436 & 1807 & 5211 & 3403 & 3119 & 3795 & 680 \\
\hline & MG & 2509 & 1399 & 2224 & 1434 & 1660 & 1845 & 222 \\
\hline
\end{tabular}

Ungrazed

${ }^{2}$ Lightly grazed

${ }^{3}$ Moderately grazed

${ }^{4}$ Data not available

Cattle were English-cross yearlings, including Angus, Red Angus, and Hereford breeds that averaged $455 \mathrm{~kg}$ (Table 3). Actual use data for pastures surrounding springs were provided in AllenDiaz et al. (1998). Livestock were managed under a comprehensive SFREC health care program, which included immunization against locally common cattle diseases several times annually.

Livestock grazing during the growing season has little effect on forage composition or productivity on California's hardwood rangelands (Bartolome and McClaran 1992). Grazed California annual grass rangelands are managed so that target residual dry matter levels are achieved at the end of the annual grass growing season (late May) or before the new rains start (September) (Bartolome et al. 1980, Heady et al. 1992). Domestic grazing animals are generally allowed to graze rangeland pastures on a semi-continuous or periodic rotational basis so that at the end of the growing season RDM target levels for the grassland are met. Animal management objectives include maintaining or enhancing body weight, and animal numbers are adjusted depending on the quality and quantity of forage available at any time during the annual grass growth cycle. Other elements of the rangeland landscape, such as springs, are not managed for per se. Rather, these ecosystems experience cattle use levels in proportion to their desirability as green forage and place of water.

Experienced Research Center annual grassland range managers monitored grazing treatment intensity during each treatment period. Cattle were left on a site until a visually estimated residual dry matter (RDM) target level was attained during any grazing period. To quantify grazing treatment levels, upland RDM was mea-

\section{Statistical analyses}

Potential differences in total herbaceous cover at springs and creeks among grazing treatments were assessed with split-plot, repeated measures ANOVA (S-PLUS 1993). Three watersheds comprised a blocking variable that effectively reduced error variance by partitioning site-to-site variability out of the ANOVA model. Each watershed was subjected to 3 grazing treatment levels (whole plot) repeatedly measured over 6 years (and 6 weeks for 1997; split plot). Homoscedasticity was verified for both factors but significant covariance among years indicated nonindependence across factor levels rendering univariate analyses inappropriate for significance tests of temporal variation (Winer 1971). Hence, MANOVA was performed on year-wise orthogonal contrasts of total cover for tests of time. Orthogonal contrasts were created by multiplying total cover by a coefficient matrix whose determinant equaled zero. MANOVA was then performed using yearly responses as dependent variables (Venables and Ripley 1997). When significant main or interaction effects were detected, pooled standard errors of the differences among means were examined to ascertain which treatment levels gave rise to significant differences main or interaction effects.

Temporal changes in plant species composition across grazing treatments were assessed with TWINSPAN, a divisive, polythetic classification program (Hill 1979). Default cut-levels were used to classify each pasture-year combination.

\section{Results}

Vegetative "hits" were determined according to the first foliar intercept in the herbaceous layer. Total herbaceous cover was calculated as total hits minus non-vegetation hits divided by total hits. Plant species identification and nomenclature followed The Jepson Manual (Hickman 1993). ceous cover at springs. Interannual variation was significant only in 1994, when total herbaceous cover was greater than cover totals in 1995 and $1997(\mathrm{P}<0.05)$.

Table 3. Cattle abundance and mean weight in each grazing period for 3 treatments. (Actual use dates and number of animals per treatment can be found in Allen-Diaz et al. 1998).

\begin{tabular}{lcc}
\hline \hline Grazing treatment period & Animal type & Animal weight \\
\hline & & $(\mathrm{kg})$ \\
November-December 1992 & cow & $360-405$ \\
March-May 1993 & cow & $360-405$ \\
November-December 1993 & cow & $360-405$ \\
March-May 1994 & cow & 455 \\
May 1994* & steer & 225 \\
December 1994-May 1995 & cow & 455 \\
February 1996-May 1996 & cow, calf & 455,214 \\
November 1996-May 1997** & cow, calf, bull & $455,214,475$ \\
\hline
\end{tabular}

*adjustment to reach RDM standards

**7 bulls for 2 days on Campbell LG 


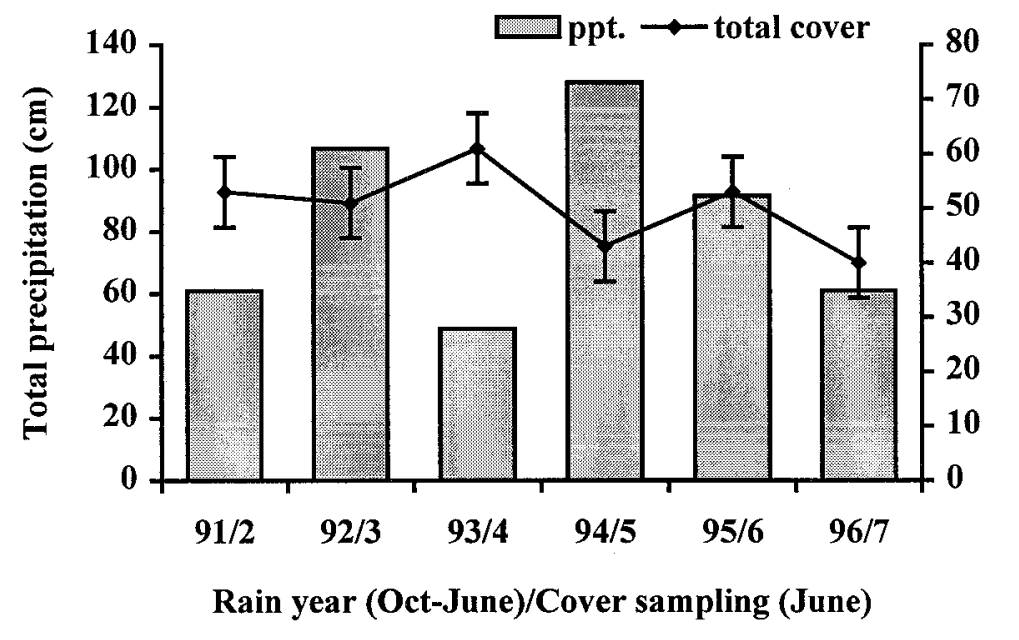

Fig. 1. Annual precipitation and total herbaceous cover at springs.

Precipitation well above average in the 1992/93 rain-year coupled with below average precipitation for the 1993/94 rain year probably contributed to increased cover in 1994 and reduced cover in 1995 (Fig. 1).

A significant grazing $\mathrm{X}$ year interaction was determined for total herbaceous cover at creek sites $(\mathrm{P}<0.05)$. Grazing treatment groups did not differ significantly for 1992 and 1993 (Fig. 2). But, in 1994, ungrazed (UG) cover increased dramatically from $63 \%$ to $86 \%$ while the moderately grazed (MG) group declined from $74 \%$ to $59 \%$ total herbaceous cover. The UG group retained greater cover than $\mathrm{MG}$ and lightly grazed (LG) in 1995 and 1996, but not in 1997. The LG group maintained the most stable total herbaceous cover val- ues over the study period ranging between $45-55 \%$. The MG group cover ranged from $80 \%$ at the beginning of the study (1992) to $34 \%$ one year after the lowest rainfall year (1994).

TWINSPAN classification analysis showed that only one spring transitioned to a new community type, a result of Rubus spp. expansion at the Forbes moderately grazed (MG) spring plot (Fig. 3). The transition occurred between 1992 and 1993 and has an associated eigenvalue $(\lambda)$ of 0.434 indicating a high goodness-ofsplit (Jongman et al. 1995). All other splits were based on dominant tree presence (Salix spp., $\lambda=0.556)$, Typha angustifolia L. presence $(\lambda=0.474)$, and Rhamnus cal ifornica Eschsch. presence $(\lambda=0.359)$, which changed little during the study.

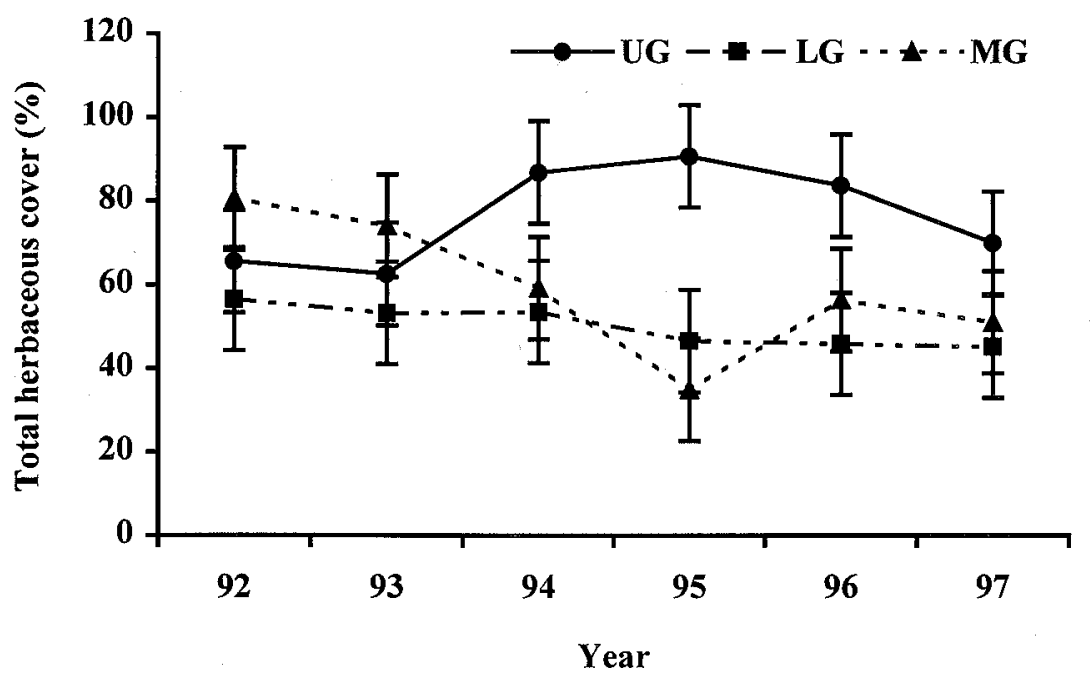

Fig. 2. Total herbaceous cover by grazing treatment at creeks.

Results based on 1997 quasi-weekly sampling showed no grazing treatment effects and no temporal variation in total herbaceous cover at springs. A year $\mathrm{X}$ grazing interaction for total herbaceous cover at creeks $(\mathrm{P}<0.01)$ reflected a difference between LG and MG for the initial 1997 sampling week (11 April). Lightly grazed and $\mathrm{MG}$ groups then stabilized at $\sim 50 \%$ herbaceous cover for the remainder of the 1997 6-week sampling period. The TWINSPAN results showed no compositional changes over the 6-week sampling period.

\section{Discussion}

Domestic livestock have grazed the Sierra Foothill Research \& Extension Center (SFREC) area for about 120 years. Although grazing intensity has certainly varied during this period, springs and their resulting creeks likely experienced periods of intense utilization, especially during summer. With the introduction of SFREC range management (1960), use at springs remained concentrated but less continuous, allowing for vegetative recovery and regrowth of perennial vegetation during rest periods. At SFREC, cattle are moved often, usually dictated by research needs.

While mean residual dry matter (RDM) target levels were met for the 6-year period, moderate- and light-grazed targets were transposed in several years (Table 2). This resulted from difficulties in reconciling visual upland RDM estimates with visual observations of spring use and because the presence of particular species at certain sites (Typha angustifolia L., Rhamnus californica Eschsch.) somewhat physically deterred riparian use until surrounding annual grasses had been heavily utilized. Moderately grazed and lightly grazed (LG) targets were also occasionally transposed because of upland vegetation regrowth under more favorable weather conditions after animals had been removed. Hence, cattle were sometimes removed from pastures before upland RDM targets were met. We do not believe that the minor interannual differences in RDM target levels affected the overall 6year results.

In fact, our study continued the 120-year history of periodic, intense use of the spring systems at both LG and moderately grazed (MG) treatment levels, but especially at MG levels. The ungrazed (UG) treatment can be thought of as release from 120 years of MG use. Grazing treatments, including complete protection, did 


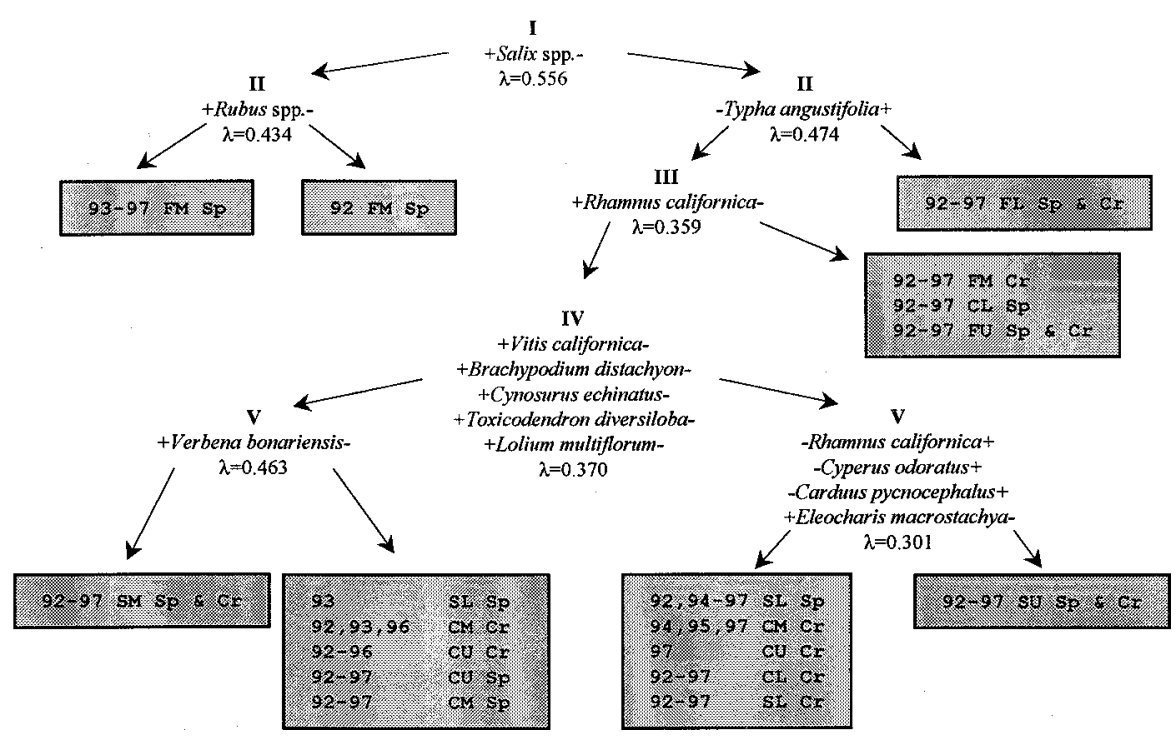

Fig. 3. TWINSPAN classification results. Roman numerals indicate different division levels. Numbers in shaded boxes indicate year, first letter denotes watershed $(F=F o r b e s$, $\mathbf{S}=$ Schubert, $\mathbf{C}=$ Campbell $)$, second letter denotes grazing treatment $(\mathrm{M}=$ moderately grazed, L=lightly grazed, U=ungrazed), "Sp" denotes spring-site, "Cr" denotes creek-site. Classification divisions were based on presence (+) or absence (-) of noted species. Strength of a given division is measured by eigenvalue $(\lambda ; 0.00-1.00$ range $)$.

not alter total herbaceous cover at springs or species composition at springs or creeks during the 6-year study.

The finding that MG plots changed in total cover more among years at creeks and springs than either the LG or UG groups, possibly under the influence of rainfall fluctuations, is compelling. Annual rainfall patterns control variations in species dominance on California's annual grasslands (Pitt and Heady 1978). It appears that these same patterns could similarly influence herbaceous cover in the perennial vegetation of low-flow spring systems, but with a 1-year time lag (Fig. 1). We did not observe interannual rainfall induced shifts in vegetation composition, an anticipated result, because seed bank, edaphic characteristics, and water, which are known to affect annual uplands, are less limiting at spring ecosystems.

We speculate that prolonged drought in moderately grazed situations probably reduces herbaceous cover at both springs and creeks, but without an immediate impact on plant community composition until some low-cover threshold is crossed (sensu Bartolome 1984). We hypothesize that soil loss and decreasing water table depth would eventually produce compositional changes on moderately grazed systems, given drought conditions. As spring flows seasonally waned, the changing pattern of water table drawdown shown to affect composition in wet meadows (Allen-Diaz 1991) should eventually induce compositional transitions. Shallowrooted annual species would move into formerly saturated areas. It is unknown whether these changes would be fluid enough that a return to pre-drought springflow would result in a linear, reverse transition to pre-drought species composition and spatial extent. However, given that this system has been moderately grazed for $120+$ years, enduring several droughts, it seems apparent that the plant communities found presently represent some relatively stable result of Mediterranean-type climatic regimes. Monitoring to detect threshold response of these spring-creek systems under continued grazing exclusion and increased grazing intensity (target $\sim 600 \mathrm{~kg} \mathrm{ha}^{-1} \mathrm{RDM}$ ) will continue.

Instead of showing more sensitivity to grazing, ample water supply seems to buffer deleterious grazing effects at springs and spring-fed creeks. This buffering apparently stabilizes perennial spring vegetation composition. We conclude that species composition is not sensitive to existing grazing systems that include periodic intense use coupled with overall moderate grazing levels on uplands. Instead, spring vegetation composition appears resistant to changes in both grazing and climatic conditions.

However, total vegetative cover appears to be a more useful metric for abiotic and biotic resource conservation in these systems. We base this conclusion on our finding that total herbaceous cover is sensitive to weather variability, especially under higher grazing intensities. Because total cover is directly linked to erosion rates and hydrologic processes (Busby et al. 1994, Busby and Cox 1994), total cover may prove to be an appropriate monitoring parameter for these systems.

\section{Literature Cited}

Allen-Diaz, B. H. 1991. Water table and plant species relationships in Sierra Nevada meadows. Amer. Midland. Natur. 126:30-43.

Allen-Diaz, B. H., R. D. Jackson, and J. Fehmi. 1998. Detecting channel morphology change in California's hardwood rangeland spring ecosystems. J. Range Manage. 51:514-518.

Bartolome, J. W. 1984. Impacts of grazing intensity and grazing systems on vegetation composition and production, $\mathrm{p}$. 917-925 In: Committee on Developing Strategies for Rangeland Management (ed.), Developing strategies for rangeland management: a report. Westview Press, Boulder, Colo.

Bartolome, J. W. and M. P. McClaran. 1992. Composition and production of California oak savanna seasonally grazed by sheep. J. Range Manage. 45:103-107.

Bartolome, J. W. and R. B. Standiford. 1992. Ecology and management of Californian oak woodlands. p. 115-118. In: Peter F. Ffolliott, et al. (eds.), Ecology and management of oak and associated woodlands: perspectives in the southwestern United States and northern Mexico, USDA Forest Serv. GTR RM-218, Sierra Vista, Ariz.

Bartolome, J. W., B. H. Allen-Diaz, and W. D. Tietje. 1994. The effect of Quercus douglasii removal on understory yield and composition. J. Range Manage. 47:151154.

Bartolome, J. W., M. C. Stroud and H. F. Heady. 1980. Influence of natural mulch on forage production on differing California annual range sites. J. Range Manage. 33:4-8.

Busby, F. E. and C. A. Cox. 1994. Rangeland health: new methods to classify, inventory, and monitor rangelands. Renewable Resources J. 12:13-19.

Busby, F. E., J. C. Buckhouse, D. C. Clanton, G. C. Coggins, G. R. Evans, K. L. Gadzia, C. M. Jarecki, L. A. Joyce, D. Loper, D. L. Merkel, G. B. Ruyle, J. W. Thomas, J. H. Wald, and S. E. Williams. 1994. Rangeland health: new methods to classify, inventory, and monitor rangelands. Com. on Rangeland Classification, Board on Agr., Nat. Res. Council. Nat. Academy Press, Washington, D.C.

Dyksterhuis, E. 1949. Condition and management of rangeland based on quantita- 
tive ecology. J. Range Manage. 2:104-115.

Heady, H. F., R. P. Gibbens, and R. W. Powell. 1959. A comparison of the charting, line intercept, and line point methods of sampling shrub types of vegetation. J. Range Manage. 12:180-188.

Heady, H. F., J. W. Bartolome, M. D. Pitt, G. D. Savelle, and M. C. Stroud. 1992. California prairie, p. 313-332 In: R.T. Coupland (ed.), Natural grasslands. Vol. 8A Elsevier, New York, N.Y.

Herbert, F. W. and E. L. Begg. 1969. Soils of the Yuba Area, California. County of Yuba, Calif., Davis, Calif.

Hickman, J. C. 1993. The Jepson Manual. University of California Press, Berkeley, Calif.
Hill, M. O. 1979. TWINSPAN-a FORTRAN program for arranging multivariate data in an ordered two-way table by classification of the individuals and attributes. Cornell University, Ithaca, N.Y.

Jongman, R. H., C. J. F. ter Braak, and O. F. R. Van Tongeren. 1995. Data analysis in community and landscape ecology. Cambridge University Press, Cambridge.

Kinney, W. C. 1996. Conditions of rangelands before 1905 , p. 31-46 In: Univ. of Calif. Centers for Water and Wildland Resources (ed.), Sierra Nevada Ecosystem Project, Final Rept. to Congress. Vol. II, Davis, Calif.

Milchunas, D. G. and W. K. Lauenroth. 1993. Quantitative effects of grazing on vegetation and soils over a global range of environments. Ecol. Monogr. 63:327-366.
Pitt, M. D. and H. F. Heady. 1978. Responses of annual vegetation to temperature and rainfall patterns in northern California. Ecol. 59:336-350.

S-PLUS. 1993. Statistical Sciences, S-PLUS Programmer's Manual, Version 3.2. StatSci, a division of MathSoft, Inc., Seattle, Wash.

Standiford, R., N. McDougald, W. Frost, and R. Phillips. 1997. Factors influencing the probability of oak regeneration on southern Sierra Nevada woodlands in California. Madroño 44:170-183.

Venables, W. N. and B. D. Ripley. 1997. Modern applied statistics with S-PLUS. Springer, New York, N.Y.

Winer, B. J. 1971. Statistical principles in experimental design. McGraw-Hill, New York, N.Y. 